\title{
MODEL OF BUSINESS ACTIVITIESS OF MICROFINANCE INSTITUTIONS IN INDONESIA
}

\author{
Etty Mulyati ${ }^{1}$, Kartikasari ${ }^{2}$; Rai Mantili ${ }^{3}$; Nun Harrieti ${ }^{4}$ \\ ${ }^{1}$ Padjadjaran University. Faculty of Law, Bandung, Indonesia, etmul21@gmail.com \\ ${ }^{2}$ Padjadjaran University. Faculty of Law, Bandung, Indonesia, kartikasari@ unpad.ac.id \\ ${ }^{3}$ Padjadjaran University. Faculty of Law, Bandung, Indonesia, raifdl@yahoo.com \\ ${ }^{4}$ Padjadjaran University. Faculty of Law, Bandung, Indonesia, nun_harrieti@yahoo.com
}

\begin{abstract}
Micro Finance Institutions (LKM) as non-bank financial institutions, are growing very rapidly in Indonesia. A very large number and scope of business in villages/sub-districts and sub-districts or districts can play a role in an inclusive financial program. The existence of LKM operation is very helpful to expand employment and to improve the welfare, the economic and productivity of the people, especially in the low-income communities. The problem is how to built the model of the business activities of LKM in Indonesia. This research will use normative juridical approach method, with descriptive analyze. In an effort to provide financial services, which are intended for the low-income communities who do not have access to the bank financial institutions, LKM can be bridge the problems solving of micro business access to capital is needed in business development. As a financial board LKM has some different character with the other financial sector businesses, wherein it is not solely intended for profit. LKM business activities can be performed in a conventional or sharia, includes loan/financing for micro enterprises for capital needs in business development, and management of deposits in an effort to bring awareness to the community's fond of saving, besides that LKM also provide consulting services for the purpose of business development community empowerment. To provide legal certainty for the LKM service user community, LKM institutions are regulated in LKM Laws, according to the law the LKM must be a legal entity of the Cooperative or Limited Liability Company Fostering, regulating, and supervising and licensing of LKM is performed by the Financial Services Authority (OJK).
\end{abstract}

Keywords: LKM, micro business, OJK

\section{Introduction}

Implementation of economic development to achieve the highly national income, is also purpose to accelerate the growth of job and reduction of unemployment rate, so that it can solve the problem of poverty. Development in the economic field has an impact on the development of business in Indonesia, either big business, medium business, or small business, and especially micro business. Micro-enterprises are the most important sectors in the development of national economic and to provide broad economic services to the community. The function and role of small-scale enterprises is very large in the economic activities of the community, including: Provision of goods and services; Employment; Equity of added value added for regional products and Increasing 
standard of living ${ }^{1}$. Thus small business is the sector that plays the most role in the development of national economic and provides broad economic services to the community, and plays a role in realizing national stability.

The capital needed to start a business on a small scale, a micro-enterprise to start a business anytime and it's easy to get started. The lower layers of society can be easily participate in the development of micro-enterprises. According to the Graphic of business deployment in Indonesia UMKM dominates 99.75 percent, and only 0.19 percent is a large-scale business. The dominance of micro business scale is 83.27 percent as many as 18.933 million business and 15,81 percent small business. ${ }^{2}$ The Indonesian Bank notes that there are some strategic roles of the small business, among them: The large number and is present in every sector of the economy, the great potential in employment as every investment in the small business sector can create more employment opportunities than the same investment in the business Medium / large, and the have the ability to utilize local raw materials and produce goods and services needed by the community at an affordable price. ${ }^{3}$

In general, the problems of micro enterprises is the lack of capital and difficulties in terms of access to financing sources. Capital loans from banks or other financial institutions are difficult to obtain because the administrative and technical requirements which are requested by the banks can not be met. The requirement which becomes the biggest obstacle for micro business is the provision about collateral, because not all micro and small businesses have sufficient assets and enough to be used as collateral. The lack of fulfillment of micro business capital requirement to bank intervention can be marked by the frequent sounding of complaints from micro business actors who have difficulty in getting access to both credit and high credit interest rate, so that can not be reached by the business man of micro business.

In order to encourage of empowerment of micro enterprises, need comprehensive support from financial institutions. To overcome the constraints of access to finance to formal financial institutions, the community has grown and developed many non-bank financial institutions that

\footnotetext{
${ }^{1}$ Sutyastie Sumitro, (2003). Analisis Ekonomi Jawa barat, Unpad Press, Bandung, p. 270

${ }^{2}$ Statistics Center Indonesia, Statistic of Indonesia

${ }^{3}$ Bank Indonesia. (2001). Sejarah Peranan Bank Indonesia dalam Pengembangan Usaha Kecil, Biro Kredit, Bank Indonesia.
} 
conduct business development services and community empowerment activities, either established by the government or the community. These institution is known as Micro Finance Institutions (MFIs). MFI is a profit motive institution that is also has a social motive, whose activities are more emphasize on community development without disregarding its role as a financial intermediary institution. ${ }^{4}$ As an institution that has the function of intermediation, MFI also performs savings and loans activities,besides providing loans but also required to provide awareness of saving to the community, especially low income people. ${ }^{5}$

For the most micro businesses to access to financing and lending rates is low, so MFIs have a very important function in the development of micro enterprises. The existence of this MFI provides a good impact to the community doing micro business, helping to increase economic empowerment and community productivity in developing its business activities. The MFI is an effort to provide financial services, especially savings, loan or financing management and other financial services, which intended to the poor and low-income families who do not have access to commercial banks. ${ }^{6}$ MFIs are chosen because a lot of micro businesses are feasible in the business but will not be bankable for the loan application process to financial institutions. ${ }^{7}$ Thus the existence of an MFI can to be the bridge of the problem in access of micro business to the fulfillment of fund needed for business development.

The advantages possessed by the MFI included fast, easy and simple services, the presence of MFIs closer to the community, so as to be more familiar with the character of the customer / borrower. The potential that MFIs can play in spurring economic growth is enormous, at least there are several reasons to support the argument: MFIs are generally located or at least close to the rural areas that can be easily accessed by economic actors in the village. The villagers prefer a short process and with no long procedure; The general characteristics require a loan ceiling that is not too large to match the financial capability of an MFI; Nearby MFIs and farmers enable MFI managers to fully understand of the characteristics of farming so they can disburse loans in a timely and

\footnotetext{
${ }^{4}$ I Gde Kajeng Baskara.(2013) Lembaga Keuangan Mikro di Indonesia, Jurnal Buletin Studi Ekonomi, Volume 18, No.2, Agustus, p. 115.

${ }^{5}$ Ibid

${ }^{6}$ Lincolin Arsyad.(2008). Lembaga Keuangan Mikro, Institusi, Kinerja dan Sustanabilitias, Andi, Yogyakarta, p. 1

${ }^{7}$ Lokakarya Nasional, Memantapkan Pola Linkage Bank - LKM Dalam Upaya Percepatan Penanggulangan Melalui KUR Mikro, Selasa 10 Juni 2009, Gedung SME’sCO Promotion Center (SPC Jakarta) 328

Diponegoro Law Review, October 2017, Volume 02, Number 02
} 
quantitative manner; The existence of socio-cultural linkages and personal-emotional relationships is expected to reduce the nature of moral hazard in credit repayment. ${ }^{8}$

In Indonesia there are many developing MFIs that do business activities in the field of finance and much help to the community, especially the poor and / or low income. The existence of MFIs in principle as a financial institution providing micro-savings and financing services, focused on micro-enterprises, with the aim of expanding employment, and improving the welfare of the poor, and being able to act as an instrument of equity and income generation Community, in improving the welfare of the poor and / or low income. Although in general the cost of borrowing funds from MFIs is slightly higher than bank interest rates, but in terms of lending procedures / administration, MFIs have several advantages. Among these advantages, for example there is no collateral requirement / guarantee as applied to formal banking. Even in some types of MFIs, lending is based more on trust because borrowers are typically known to the MFI's managers. Another convenience is the disbursement and repayment of loans is very flexible and often tailored to the borrower's cashflow. ${ }^{9}$

MFI practices in Indonesia have evolved over the decades, into different institutional forms using both conventional and shariah models. This development is followed by the number of MFIs that grow very rapidly. Therefore, it must be acknowledged, the potential of MFI is needed by both central and local government to facilitate micro business actors from the aspect of financing and business assistance.

In line with the Constitution of the State of the Republic of Indonesia Year 1945 (UUD 1945) Article 33 paragraph (1) affirms that the economy is prepared as a joint effort based on the principle of kinship. Subsequently Article 33 Paragraph (4) of the 1945 Constitution states that the national economy is organized based on economic democracy with the principles of togetherness, fair efficiency, sustainability, environmental insight, independence, and by maintaining the balance of progress and national economic unity. MFIs are basically formed based on the spirit contained in Article 27 paragraph (2) and Article 33 paragraph (1) and paragraph (4) of the 1945 Constitution.

\footnotetext{
${ }^{8}$ Ashari, (2006). Potensi Lembaga Keuangan Mikro (LKM) Dalam Pembangunan Ekonomi Pedesaan dan Kebijakan Pengembangannya, Analisis Kebijakan Pertanian, Volume 4 No. 2, p. 151

${ }^{9}$ Ihwan Susila,(2007), Analisis Efisiensi Lembaga Keuangan Mikro, Jurnal Ekonomi Pembangunan , Vol. 8, No. 2, Desember, p. 226.
} 
Based on this, to meet the financial services needs of the poor and / or low income, A law on MFIs. In order to provide a strong legal basis and legal certainty over the operationalization of the MFI, then on January 8, 2013 has been enacted Law No. 1 of 2013 on Micro Finance Institutions (MFI Act).

Why MFIs need to be regulated in legislation, in view of Article 16 paragraph 1 of Law no. 7 of 1992 as amended by Act no. 10 year 1998 concerning Banking (Banking Law), that any party conducting the activity of collecting funds from the public in the form of savings shall first obtain business license as a Commercial Bank or Rural Bank from the Management of Bank Indonesia (now the authority of the Financial Services Authority), Unless the activities of collecting funds from such public are governed by a separate law. Based on this, the MFI is governed by the MFI's Law to provide legal and legal certainty to the MFI's many operating activities in the community so that financial services to the poor or low-income people can be met.

With the issuance of the MFI Act has provided a legal umbrella for the activities of MFI activities, so that the activities are legal while if you do not have permission in accordance with laws and regulations including illegal. However, the institutions that run the MFI business are many who are not yet legal entities and do not yet have business licenses, as mandated in the MFI Act. A large and diverse number of different types of MFI services as well as a wide range of business areas. The problem is how to model business activities and regulate and supervise MFIs in Indonesia.

\section{Research Method}

The approach method which used is normative juridical approach method, which included positive law invention, the principles of law, systematical of law, historical of law and comparative of law researches researches researches. ${ }^{10}$ This research by examining to the library or secondary data that obtained from libraries and related institutions that are competent with this research. As normative legal researchwith on secondary data in the form of primary legal materials, secondary

\footnotetext{
${ }^{10}$ Ronny Hanitijo Soemitro, (1990), Metodelogi Penelitian Hukum dan Jurimetri, Ghalia Indonesia, Jakarta,p. 9-10 330 
law materials and tertiary legal materials. ${ }^{11}$ In this research will be examined about the legal aspects of the model of MFI activities in Indonesia, especially on legal issues that have been identified.

The specification of this research is analytical descriptive, that making a systematic description of the facts ${ }^{12}$ including describing the rules ${ }^{13}$. Thus, this study will illustrate various legal issues that obtained through the invention in positive law, the discovery of legal principles and the in concreto legal discovery of the MFI which aims to obtain a comprehensive and systematic picture through an analytical process using legal rules, legal principles and legal understanding MFI.

Data analysis method used in this research is qualitative normative analysis method. Normative analysis because this research is based on laws and regulations that apply as positive legal norms, while qualitative is the research method that is centered to obtain descriptive data, through what is stated by the speakers both orally and in writing as well as the fact that happened.

\section{Results and Discussion}

Based on the explanation of the MFI Act, the financial sector in Indonesia is one of the sectors that have an important role in encouraging the improvement of the national economy and the economy of society. The development and progress in the financial sector, whether banks or nonbank financial institutions need to be maintained. In the institutional, organizational, regulatory, policy, and human resource (HR) aspects need improvement and improvement, especially in nonbank financial institutions. In Indonesia, many developing non-bank financial institutions that conduct business activities in the financial sector that much help to the community. These institutions need to be developed, especially in their institutional and legality since they have helped to improve the economy of the community, especially the poor and / or low income and micro business actors. Developments in today's society, financial institutions that provide funds or capital for micro-scale enterprises and small-scale enterprises are very important. These micro-finance institutions are only focused on micro business community. These micro-finance institutions are known as MFIs.

\footnotetext{
${ }^{11}$ Soerjono Soekanto dan Sri Mamudji,(2006), Penelitian Hukum Normatif suatu Tinjauan Singkat, Rajawali, Jakarta, 2006, p. 13-14.

${ }^{12}$ Op.cit. p. 22

${ }^{13}$ Sumadi, (1988), Metode Penelitian, CV Rajawali, Jakarta, p. 19
} 
Understanding the MFI in Article 1 point 1 The MFI law is a financial institution specifically established to provide business development services and community empowerment, either through loans or financing in micro-scale enterprises to members and communities, the management of savings, as well as the provision of business development consultancy services Which is not solely for profit. Based on this understanding, it can be illustrated the business activities of the MFI, which includes business development services and community empowerment, either through loans or financing in micro-scale enterprises to members and communities, the management of savings, as well as the provision of business development consulting services.

Business activities may be made in a conventional manner or based on Sharia Principles. In carrying out business activities based on Sharia principles shall be carried out in accordance with the Sharia fatwa issued by the National Sharia Council, Majelis Ulama Indonesia. Conventional MFIs may not conduct business activities based on sharia principles, MFIs must choose to run business activities in a conventional or sharia-based manner. An MFI conducting business based on Sharia Principles is obliged to use a contract in accordance with Sharia Principles.

In conducting business activities, the MFI is prohibited: to accept deposits in the form of demand deposits and to participate in payment traffic; Conducting business activities in foreign currency; Conducting insurance business as an insurer; Acting as guarantor; Provide loans or financing to other MFIs, except in the context of overcoming liquidity difficulties for other MFIs within the same districts / municipalities; And conducting business outside the business of borrowing or financing and managing savings and providing business development consulting services.

MFIs have a different character from other financial sector businesses, the presence of MFIs is not only for profit, it also increases the income and welfare of the people and fosters economic empowerment and community productivity by facilitating the poor and low-income people, especially micro businesses. This is as set out in Article 3 of the MFI Act, that the MFI aims to: improve access to micro-finance for the community; To help increase economic empowerment and community productivity; And help increase the income and welfare of the people; Especially the poor and / or low income. 
This is seen through the type of MFI business activities that include loans or financing in micro-scale enterprises, savings management, and business development consulting services that estuary of all is community empowerment. In its development MFIs may also engage in fee-based business activities as long as they do not conflict with the provisions of legislation in the financial services sector. Fee-based business activities, for example, market financial services products such as microinsurance, cooperate with finance companies through channeling or joint financing, or become an Officeless Finance Officer for Inclusive Finance. Being an agent of Smart Manners aims to be able to further encourage the growth of MFIs and accommodate the dynamics in the field as well as harmonization with the OJK policy regarding Smart Behavior.

In addition to conducting business activities for the collection and channeling of MFI funds conducting business based on Sharia Principles can perform the management of social funds and virtues in the form of zakat, infak, alms, and endowments in accordance with applicable laws and regulations. Bookkeeping on the management of social and benevolent funds is done separately, from savings accumulation activities and disbursement of Financing which is the main activity of the MFI concerned. The activities of advisory and business development services shall be conducted by means of an ijarah, ju'alah or other contract that is not contrary to Sharia Principles and approved by OJK.

Business development and community empowerment, conducted through loans or financing. Loans are the provision of funds by the MFI to the community that must be returned in accordance with the contract. Financing is the provision of funds by the LKM Syariah to the community which must be returned in accordance with the promised with the principles of sharia. ${ }^{14}$ The business activities of the distribution of financing shall be conducted by using a mudharabah contract, musyarakah, murabaha, ijara, salam, istishna, ijarah muntahiah tamlik bit, or other contract which is not contrary to Sharia Principles and approved by the Financial Services Authority (OJK).

MFI arrangements related to lending or financing as business development and community empowerment services are as follows: MFIs are required to analyze the feasibility of lending or financing disbursements. Establish and announce to the public the maximum interest rate on the loan or the maximum return on the financing to be applied. Obligatory to report maximum loan interest

${ }^{14}$ Article 1 Number 3 dan 4 MFI Act 
rate or maximum return of financing to OJK. The MFI is required to report to OJK, in case of raising the maximum interest rate. MFIs are prohibited from applying lending rates or return on financing beyond the maximum loan interest rate or the latest financing yields reported to OJK. MFIs are required to meet the maximum lending or financing limits for each customer, and assess the quality of loans or financing disbursed and establish an allowance for loan or financing disposal.

The lowest loan or financing limit served by the MFI is Rp 50,000 (fifty thousand Rupiah), while the maximum lending or financing limit is set at the maximum of $10 \%$ (ten percent) of the MFI's capital for group clients and a maximum of $5 \%$ (five percent) Of the MFI's capital to a single customer. What is meant by group customers is a group of citizens within the village / sub-district, sub-district or regency / city region that collect themselves in one group based on the similarity of business, identity, or purpose. For example: farmer groups, fishermen groups, and so forth.

The MFI as a financial institution facilitates its customers to deposit funds in the form of savings or deposits. Business activities for the collection of Deposits by Islamic MFIs shall be conducted using a wadiah, mudaraba or other contract that is not contrary to Sharia Principles and approved by OJK.

One important aspect of the existence of this MFI is to invite people to love to save money, this community fund saved will be managed by MFIs to be able to support the empowerment of the savings. Many of the advantages possessed by the MFIs attract public attention to become clients in the MFI, such as the short-term deposits in the MFI that is 1 month, 3 months, 6 months and 12 months. In addition, some MFIs also issue savings that are not available in banking products, such as Group Savings, Non-Member Group Savings, Savings Blessing Qurban, Savings Blessing Fitri, Student Blessing Savings, Education Savings and Fertilizer Savings.

Under the MFI Act the terminology used for depositors is Storage. The Depositary is the party who places the funds in the MFI under the agreement. While the intended savings are funds entrusted by the community to the MFI in the form of savings and / or deposits under the depositary agreement. ${ }^{15}$ With the agreement, the legal certainty of the depositors will be maintained because there is a legal relationship between the depositor and the MFI. Agreements between the customer and the MFI in carrying out the deposit of funds generally use the standard agreement, which the

${ }^{15}$ Article 1 Number 5 dan 6 MFI Act 334

Diponegoro Law Review, October 2017, Volume 02, Number 02 
contents of the agreement have been determined by the MFI. Based on the provisions of the Financial Services Authority Regulation Number 13 / POJK.05 / 2014 concerning the Implementation of Microfinance Institution Business Article 10 states that in carrying out the MFI saving management activities shall administer Storage Deposit and provide evidence of Deposit. The minimum value limit for deposit opening services is set at Rp 5,000 (five thousand Rupiah).

In the management of MFI savings as a financial institution that can receive customer funds savings must certainly guarantee the deposits of its customers, so that customers feel safe, comfortable and the certainty as well as saving funds in the bank. The MFI's Law accommodates the depositors' deposits set forth in Article 19 paragraph (1) that in order to guarantee the MFI's savings, the Regional Government and / or MFI can establish an MFI Deposit Insurance Agency (LPSLKM). Paragraph (2) states that if necessary, the Government together with the Regional Government and MFI may establish an MFI guarantor institution.

It should be underlined that the word "can" is not required to form LPS-LKM, this will cause concern for the customers who want to save funds in MFIs, especially the micro business actors. There are differences in underwriting of customer funds when compared between banks and MFIs as fellow financial institutions. Within the Banking Act it is affirmed that each bank is required to guarantee public funds deposited with a bank by establishing a Deposit Insurance Corporation (LPS). ${ }^{16}$ The existence of LPS has provided legal certainty to the customers in saving funds at the bank, if at any time the bank has failed business which in the end in liquidation. Likewise, in the case of a fund-storage agreement between the customer and the MFI can not be eliminated the possibility if there will be a default or the MFI experienced a business failure or revoked its business license. If this happens then the government should provide legal protection to the users of the MFI's services, so as not to undermine public confidence in the MFI. When the MFI loses the trust of the community, especially the small community who becomes the main figure of the MFI service user, the role of the MFI will be lost.

Prior to the enactment of the MFI's Law, the validity of the MFI in Indonesia is based on the Joint Decree of the Minister of Finance, the Minister of Home Affairs, the Minister of Cooperatives and Small and Medium Enterprises, and the Governor of Bank Indonesia Number: $351.1 ।$

\footnotetext{
${ }^{16}$ Article 37B Point (1) and (2) Banking Act
} 
/KMK.010 / 2009, Number: 900 -639A Year 2009, Number: $01 \backslash /$ SKB \/M.KUKM \/ IX \/ 2009, and Number: 11 \/43A \/KEP.GBI \/ 2009 on Development Strategy of Microfinance Institution. Based on the SKB, an unlicensed MFI group such as the Rural Credit Board, Lumbung Pitih Nagari, the Savings Pinjam Economic Unit, BMT and others, are directed to BPRs, cooperatives or village-owned enterprises. This is in line with Article 58 of the Banking Law, that: Village Bank, Village Lumbung, Market Bank, Employee Bank, Lumbung Pitih Nagari (LPN), Village Credit Institution (LPD), Village Credit Board (BKD), Kecamatan Credit Board (Badan Kredit Desa BKK), Small-Scale Business Credit (KURK), Sub-district Credit Institution (LPK), Village Production Work Bank (BKPD) and / or other equivalent institutions are granted the status of Rural Bank under this law by fulfilling the requirements Procedures established by Government Regulation.

Associated with licensing after the coming into effect of MFI Law, that MFI must have a business license from OJK. To obtain a business license must meet the least requirements regarding: Organizational structure and management; Capital; Ownership; And Feasibility of the work plan. In obtaining the permit the MFI shall apply to the OJK Office / Regional Office / Directorate of Microfinance Institutions in accordance with the position of the MFI by complying with the terms and conditions set forth in the POJK No. 61 / POJK.05 / 2015 on Amendment to POJK No. 12 / POJK.05 / 2014 on Business Licensing and Institutions of Micro Finance Institutions. In addition, the provision of business licenses for institutions that have operated before the MFI Act with the inauguration of the MFI.

The institutions that are required to obtain business licenses through Inauguration as MFIs to OJK no later than January 8, 2016. are Village Bank, Village Lumbung, Market Bank, Employee Bank, Village Credit Board (BKD), Kecamatan Credit Board (BKK), Credit Small Business Enterprises (KURK), Sub-district Credit Agencies (LPK), Village Production Work Banks (BPR), Baitul Maal wa Tamwil (BMT), Baitul Tamwil Muhammadiyah (BTM), and / Other equivalent institutions which have been established and have operated prior to the coming into effect of the MFI's Law, and have not obtained a business license under applicable laws and regulations. OJK provides an additional time period, as well as providing convenience such as applying for a noncash initial capital deposit. As of early February 2016 there have been 34 MFIs already licensed.

\section{6}

Diponegoro Law Review, October 2017, Volume 02, Number 02 
The number increased significantly because on January 8, 2016 newly registered 20, MFIs entirely in the form of cooperative legal entities.

While Lembaga Perkreditan Desa and Lumbung Pitih Nagari and similar institutions that have existed before the MFI Act apply, are declared recognized existence based on customary law and not subject to MFI Law. With the reason that a customary village is an autonomous governmental entity, it is feared that this regulation will reduce the authority of the adat village in the management of its financial institution.

Inauguration of the MFI to be a legal entity is a series of MFI supervisory and supervisory programs. The form of an MFI's Legal Entity is a Cooperative or Limited Liability Company (PT), for a legal entity of at least 60 percent owned by the local government of a regency / municipality or village-owned enterprise, the remaining shareholding of a PT may be owned by an Indonesian citizen or cooperative with ownership WNI at most by 20 percent. For an MFI with a legal entity which is entitled to authorize the MFI's Articles of Association is by the Minister of Law and Human Rights, while for MFIs legal entity Cooperative endorsement is given by the Minister of Cooperatives and Small and Medium Enterprises

MFI ownership can only be owned by Indonesian citizens; Village-Owned Enterprises; Regency / City Government; And / or Cooperatives. MFIs are prohibited to be owned directly or indirectly, by foreign nationals and / or entities that are partly or wholly owned by foreign nationals or foreign business entities.

MFI supervision, regulation and supervision is conducted by OJK. Guidance and supervision is delegated to the Regency / City Government. Based on POJK No. 14 / POJK.05 / 2014 on Guidance and Supervision of MFIs in conducting guidance and supervision, OJK coordinates with ministries conducting cooperative and interior ministry affairs. In the event that the Regency / City Government is not ready, OJK may delegate the guidance and supervision to other appointed parties.

In the framework of the implementation of supervisory and supervisory functions, OJK may conduct an Examination of MFIs and OJKs may conduct Direct Investigation of MFIs individually or jointly with District / City Government or other appointed parties. 
The scope of the business area of an MFI is located within one village / sub-district, subdistrict, or district / municipality area according to the business scale of each MFI. The MFI's business scale is determined on the basis of the borrower or financing customer distribution, ie the MFI that has the business scale of the village / kelurahan if providing loans or financing to the population in 1 (one) village / kelurahan; And MFIs have the scale of the kecamatan business if they provide loans or financing to the population in 2 (two) villages / kelurahan or more in 1 (one) the same subdistrict area; MFIs have district / city business scale if they provide Loans or Financing to residents in 2 (two) sub-districts or more within 1 (one) same regency / municipality. An MFI intending to expand its business area is obliged to adjust its business license in accordance with the scope of the new business area.

The capital to establish an MFI consists of paid up capital for an MFI or a principal savings, mandatory savings, and a grant for an MFI with a legal entity cooperative. The amount of paid up capital or principal savings, mandatory savings, and MFI grants is set at least: 50,000,000.00 (fifty million rupiahs), for an MFI with coverage of the village / kelurahan business area; 100,000,000.00 (one hundred million rupiahs), for an MFI with coverage of the kecamatan business area; Or Rp 500,000,000.00 (five hundred million rupiahs), for an MFI with coverage of the district / city business area. At least $50 \%$ must be used for working capital.

Micro Finance Institutions (MFIs), both conventional and syariah-based, are expected to realize safe, affordable, and accessible financial services to meet the needs of the community to the layers of rural communities, especially low-income and micro-entrepreneurs. MFIs can only provide financial services to the broadest community in 1 (one) district / city to be able to act as an instrument of equity and increase the income of the community, and improve the welfare of the poor and / or low income. The MFI's law mandates that the MFI can extend the reach of financial services to people outside the district / city by transforming into a bank. Transformation is a change in the business of a Conventional MFI into a BPR or a Sharia LKM to an SRB.

The MFI is obliged to transform into a rural credit bank or sharia financing bank when conducting business activities in excess of 1 (one) regency / municipality in which the MFI's position, or an MFI has an Equity of at least 5 (five) times of the minimum paid up capital requirement of the $\mathrm{RB}$ or $\mathrm{SRB}$ In accordance with the provisions of laws and regulations, and the 
amount of third party funds in the form of deposits compiled in the last 1 (one) year at least 25 (twenty five) times of the minimum paid up capital requirement of RB or SRB in accordance with the provisions of legislation.

MFIs may be dissolved, in the event that the MFI's effort does not solve liquidity and solvency problems in the MFI's business, OJK will revoke the MFI's business license and instruct the MFI Board to immediately hold a general meeting of shareholders or member meetings to dissolve the legal entity MFI and form a liquidation team. The liquidation team is tasked with completing the rights and obligations of the MFI. Dissolution of the MFI's legal entity, the formation of a liquidation team, and the settlement of rights and obligations are carried out in accordance with the legislation. The liquidation team shall submit a report on the progress of liquidation implementation to OJK at least 1 (one) time in 6 (six) months. And reporting the implementation of liquidation to shareholders or members, and OJK, no later than 3 (three) months from the date of completion of liquidation implementation.

In the framework of the implementation of supervisory and supervisory functions, OJK may conduct an Examination of MFIs and OJKs may conduct Direct Checking of MFIs individually or jointly with District / City Government or other designated parties.

Any MFI that violates the terms may be liable to: fines of money; Written warning; Suspension of business; Dismissing the board of directors or the board of the MFI and subsequently appointing and appointing a temporary replacement until the General Meeting of Shareholders or Meeting of Cooperative Members appoints a permanent replacement with OJK approval; Or revocation of business license. The imposition of such administrative sanctions is in accordance with the level of violations committed by the MFI.

\section{Conclusion}

In an effort to provide financial services, which are intended for low-income communities and do not have access to bank financial institutions. MFIs can bridge the problems of microenterprise access to capital needed in business development. MFIs have a different character from other financial sector businesses, because they are not solely aimed at making a profit. MFI business 
activities can be done in a conventional or sharia-based manner, including loans / financing in a micro-scale enterprise for capital needs in business development, and savings management as an effort to provide awareness to the public to enjoy saving, while the MFI also provides business development consultancy services The goal is community empowerment. To provide legal certainty for the MFI service user community, MFI institutions are regulated in MFI Laws, according to the law the MFI must be a legal entity of the Cooperative or Limited Liability Company. The supervision, arrangement, and supervision and permission of MFIs is done by OJK. If conducting business activities beyond a regency / municipality territory or having met the requirements set forth in the Financial Services Authority Regulation, the MFI shall be transformed into a Rural Bank (BPR).

\section{References}

\section{A. Books}

Lincolin Arsyad (2008), Lembaga Keuangan Mikro, Institusi, Kinerja dan Sustanabilitias, Andi, Yogyakarta.

Ronny Hanitijo Soemitro (1990), Metodelogi Penelitian Hukum dan Jurimetri, Ghalia Indonesia, Jakarta.

Soerjono Soekanto dan Sri Mamudji (2006), Penelitian Hukum Normatif suatu Tinjauan Singkat, Rajawali, Jakarta.

Sumadi (1988), Metode Penelitian, CV Rajawali, Jakarta.

Sutyastie Sumitro (2003), Analisis Ekonomi Jawa barat, Unpad Press, Bandung.

\section{B. Legislation}

\section{Constitution}

Law no. 7 of 1992 as amended by Act no. 10 of 1998 on Banking

Law Number 1 Year 2013 about Micro Finance Institution (MFI Act).

\section{0}

Diponegoro Law Review, October 2017, Volume 02, Number 02 
Government Regulation Number 89 Year 2014 concerning Interest Rate of Loan Or Return on Financing and Area Coverage of Business Area of Micro Finance Institution.

POJK Number 14 / POJK.05 / 2014 on the Development and Supervision of Microfinance Institutions.

POJK No. 61 / POJK.05 / 2015 on Amendment to the Financial Services Authority Regulation No. 12 / POJK.05 / 2014 on Business Licensing and Institutions of Microfinance Institutions.

POJK No. 62 / POJK.05 / 2015 on Amendment to the Regulation of the Financial Services Authority Number 13 / POJK.05 / 2014 on the Implementation of Microfinance Institutions.

SEOJK Number 29 / SEOJK.05 / 2015 on Financial Statements of Microfinance Institutions

\section{Other Resources}

Statistics Center Indonesia, Statistic of Indonesia

Ashari,(2006), Potensi Lembaga Keuangan Mikro (LKM) Dalam Pembangunan Ekonomi Pedesaan dan Kebijakan Pengembangannya, Analisis Kebijakan Pertanian, Volume 4 No. 2.

I Gde Kajeng Baskara,(2003) Lembaga Keuangan Mikro di Indonesia, Jurnal Buletin Studi Ekonomi, Volume 18, No.2.

Ihwan Susila,(2007), Analisis Efisiensi Lembaga Keuangan Mikro, Jurnal Ekonomi Pembangunan , Vol. 8, No. 2.

National Workshop, Memantapkan Pola Linkage Bank - LKM Dalam Upaya Percepatan Penanggulangan Melalui KUR Mikro, Selasa 10 Juni 2009, Gedung SME’sCO Promotion Center (SPC Jakarta). 